\title{
INTERNATIONAL RELATIONS THEORY AS SOCIAL SCIENCE
}

\section{BURCU BOSTANOĞLU}

\begin{abstract}
Although its subject matter covers decisions and pratiques whose direct or indirect influence on the lives of states, countries and therefore, individuals cannot be neglected, the study of International Relations (IR) has yet failed to achieve a status of proper science. This essay inquires the relative position of the discipline versus general social theory, its comparative poverty in the epistemological ${ }^{1}$ and methodological alternative approaches and poses the question whether this poverty is an outcome of the theoretical poverty; or more concisely, the domination of the discipline by one single paradigm for half a century: Realism. So far, the study contends, the political and social milieu in which International Relations has developed as an academic pursuit, was not sufficiently ripe for a competition of theoretical perspectives. The occurrences of the last two decades in the field have reflected on the perception and conceptualization of states' relations with each other and on a plethora of theoretical approaches the basic tenet of which is an opposition to the positivist oriented realist theory of IR.
\end{abstract}

\section{Closure in International Relations Theory:}

Particularly for practitioners of politics, IR was conceived as the act of forming pragmatical and practical responses to adapt to the realities and facts of world politics. It can safely be argued that within such a narrowised framework there exists not much need for any theoretical approach. However,

\footnotetext{
${ }^{1}$ Epistemology, as a general definition, is used here after Gill and Law (1988: 19 ) as the theoretical nature of and conditions for the acquisition and growth of knowledge. Different epistemologies are associated with different philosophies of science such as empiricism, rationalism etc. Each gives rise to a different criteria of appraisal.
} 
that is not accepted to be the case. It is still theories through which facts are attributed their meanings and render them available to analysis. As Gabriel Almond (1965) pointed out in relation to diplomatic, military, propaganda and foreign aid programs in U.S. foreign policy, a sound theory of social and cultural change as a basis of determining such policies is necessary (Shafer, $1988 ; 12-13$ ). Almond has thus established that a scientific study (or practical policy) is groundless without conceptual frames of reference.

Realist policy (including its more up to date version, Neo-realism) which has monopolized IR theory since World War II has assumed that international relations play no part or exert no influence whatsoever in the everyday lives of societies or individuals; as events that can be studied by reducing to the behavior of political decision making and executive mechanisms (Waltz, 1979; 62-64).

This formulation has limited the field of scientific attention in IR to focal empirical incidents end "bchavior of states" as sole actors of interstate relationships. An evaluation and accounting of events in current political conjonctures was considered sufficient to satisfy valid scientific requirements of the Realist paradigm (see Little, 1980, 9). The need to refer to multiple theoretical frameworks was hardly felt; the epistemological void was filled by realism in reference to which events and facts could be attributed with meaning and could be explained by generalised scientific laws. Realism, a theory that almost spontaneously emerged to fill this void, can be viewed as a demonstration that any field of academic interest, has to be guided intellectually by theory in order to be considered a scientific discipline. The reason IR has yet failed to evolve into a social science per se is perhaps a consequence of the theoretical poverty that the realist domination has caused in the ficld.

\section{Theory:}

\section{International Relations on the Grounds of Social}

Social Theory, the blanket name for all aspects of scientific inquiry into human activities and institutions that includes international relations as well, has always been rich in regard to the simultaneous competition of a variety of conceptual approaches that not only conceive the same events and facts in different frameworks but also explain them with differing laws. The competing social paradigms each other to establish their methods of scientific procedures of confirmation or falsification; which has constituted the dynamics of the epistemo-historical procedure of rivalling theories in the Kuhnian ${ }^{2}$ sense. The history of scientific revolutions emerges as the

${ }^{2}$ In his watershed views on epistemology, Thomas Kuhn maintained that a paradigm, once established can only be replaced by another which can cull a 
replacement of one dominant paradigm by another (Kuhn, 1962: 52-53, 77, $82,89-93,145-146,157)$.

The only paradigmatic rivalry in the field of IR to speak of, is the replacement of the pre-World War II idcalist approach by realism, an approach much begging to be called a proper theory with its normative and prescriptive attitude (Smith, 1987: 192; Bull, 1972). This designates realism, as the sole theory ever in IR; whose genesis (or more precisely, academic victory) coincides with the energence of a world political order as the U.S. its active and central power and which secks answers to questions that are in majority, U.S. oriented. In fact, the focus of modern criticism against realism has maintained that it has nourished an organic relation to the political praes of the U.S. and has carried over its social and political ideology to IR. However, the role of scientific claims by realism as an idcology and valuc free theory should not be overpassed in its near universal academic popularity either [not withstanding the recent critics' ${ }^{3}$ contention that realism is a reflection of American policy and ideology in IR]. That its validity as a paradigm has come to be questioned is no coincidence; the emergent world political atmosphere has opened up new spheres of conception in international relations which cannot be gauged any longer with the conventional methods of analysis so securely established in the old pattern of relations that belong to a former pattern. As Hegel said, thought never generates in vacuo.

\section{The Epistemological Heritage of Social Theory:}

The development of theory in social science in the 17-18th centuries is a resultant of efforts to clear the field of the influences of, first theology and then, philosophy historically accoupled to the genealogy of industrialized and differentiated urban societies. Sociology, psychology and cconomy have not only created their individual, independent fields but also have adopted methodologies -mainly after those of natural sciences- that established them as proper sciences (Tolan, 1993: 137-141). The advantage of general social theory was its inheritance from philosophy some kind of answer(s) to the quintessential question "what is knowledge and how is it acquired?"; and the epistemo-methodological infrastructure generated by the responses (Bostanoğlu, 1995; Tolan, 1993: 137-141).

Political science (of which IR is generally considered a part), perhaps the youngest member on the genealogical tree of social sciences constitutes a good example of this: The debate whether the discipline should more

number of followers who adhere to its practices of "normal science", i.e., its praxes of laws, theory, application and instruments (Kuhn, 1962: 89-93; 145-146).

${ }^{3}$ Richard Ashley, James DerDerian, Michael Shapiro, Robert Cox, Andrew Linklater, R. B. J. Walker to name a few "critics". 
appropriately be called "political sociology" continues (Sarıbay, 1994: 2328). A predominantly American academic endeavour, it has become a widely adhered field in Europe as well borrowing largely from the epistemology and methodology of other social sciences. Its American tilt has colored political science with a noticeable positivist -empiricist tint as the favored position of the U.S. academe; however, on both side of the Atlantic a strong albeit diffuse voice of nonpositivist dissent fulfilling Kuhn's measures of a paradigm has also commanded a considerable audience (Birnbaum, 1988: 611). In their diffusion, the dissentive paradigms have coexisted despite their incommensurability (Neufeld, 1993: 69). Rosenau (1982) stresses the role of personal and circumstantial factors that lead scientists to the choice of a paradigm whereas Imre Lakatos points out to the coexistence of competing Scientific Research Programs which interpret and explain facts differently (Ncufcld, 1993: 70; Nicholson, 1992: 37; Lakatos and Musgrave, 1974). Even within the same program (paradigm) a consensus or convergence is not necessary: The psychological theorics of frutration and aggression coined by the Yale Group and Berkowit\%, the Social Learning Theory of Albert Bandura; the Social Influence theory of James Tedeschi are incommensurable and incompatible except for the strict adherence to the canons of positivist social theory (Isen, 1995: 73-87).

Even within the positivist "research program" IR has remained poor in regard to competing theories. Since Comte, positivism has ruled Western social science. In the ficld of IR, the manifest positivist approach has been realism in the last half century. The recent opposition to realism since the 1980 's often stem from a rejection of the positivist mentality which applies the methods of natural sciences to social phenomena. This dissent, which can be traced back to the "Critical Theory" of the Frankfurt School or the post Wittgenstein and post Winch approaches which emphasize the specificity of cultural differences via linguistic theories and post modernist rejectionism also draw largely on the liberating epistemological trajectorics of Kuhn (Jones, 1995, 13).

Nonrealist IR theories do not gather adherents coincidentally or merely because their discourse is suddenly understood better. As Robert Cox (1992: 444) wrote, theory is always for someone and serves some purpose. Perspectives ${ }^{4}$ which are reflected in the theorics they generate, crystallize dependently on political time and space. Each perspective emerges in a given historical and institutional context. The range of variation from perspectives

\footnotetext{
${ }^{4}$ Cox (1986: 207) defines perspective as the theoretical and practical viewpoints of political and coalitions of groups, institutions and movements which contains their Weltanschauungen and identities. A perspective includes not only a certain ideology but also a theory or theories which is adhered to by certain interests or in relation to them.
} 
of theories they engender is dependent on the academic community and wider political forces, according to Cox (1986: 207) who thus points out to a further delineation of the limits Kuhn has drawn for paradigms in reference to scientific communities as regards the sciences with a direct socio-political content. From this viewpoint, a closer look at the "perspective" realism as a positivist theory reflects will serve to clarify the relationship between social reality and social science. Especially where studies of social phenomena are concerned, the socio-political functions of science play a large role in determining the dominant paradigm. The secular, centralized, industrialized capitalist societies of the immediate post-Enlightenment Europe have, on the one hand opposed and guarded social sciences against the penetration of philosophy which was a possible threat of reinviting theology to this liberated domain; on the other the socialist movements of the 19th century has caused a coexistence, maybe even a codevelopment of conservative and radical theories. These incompatible approaches have rendered social science "an ideological as well as scientific" endeavour as "the science of the new industrial society" (Bottomore, 1977; 9). The roots of contemporary paradigmatic debates can casily be traced to this period when the argument between the positivists who propagated the application of natural scientific method to socicty and those who put the emphasis on social change; viewing social phenomena as specific, goal directed, meaningful dynamics rooted in the process of history. The latter who naturally insisted on specific methods specially devised to study socio-historic phenomena have referred to themselves as dialecticians, reflective theorists, reconstructionists, deconstructionists, post-structuralists or postmodernist (Bottomore, 1997; Der Derian and Shapiro, 1989; Onuf, 1989).

Science does not occur in vacuo. Regardless of its immediate, direct practical consequences, in a sense, it functions as a cognitive system of society in determining and conceptualizing questions concerning experiences lived, as well as a systemization of probable and possible answers. Therefore although the questions and problems may be defined by the particular time and space of such experiences, the subject of science is the past, present and future relations (real and potential) that form socicty. The transformations of post-scholastic Europe have resulted in questions and problems unanswered by the previously valid theological - metaphysical paradigms and the study of both nature and society as subjects independent from celestial decrees.

Positivism which bases its conception of truth on an instrumental rationality that seeks a correspondence between theoretical assumptions and empirically testable reality has a fundamental claim of being value free and objective, therefore scientific. The social science version of this claim reads "ideology free". This empirically gathered and tested knowledge of the facts of the world reflects outside reality "here and now" (Sargut, 1994: 27-28). Thus a clearcut distinction between a dichotomized subject and object, the observer and the observed, subjectivity and objectivity, agency and structure, 
universalism and particularism etc., becomes the operational method of achieving the positivistic knowledge of reality (Neufeld, 1993: 55-56).

The "here and now" approach of positivism toward society and its phenomena fixes events at their final point of investigation in time and space. A continuing flow of time and the changes it incurs are reduced to generalizations or universal laws that defy time and place, assuming and asserting that, given the same conditions, the same causes will produce the same results here and now, in the past or in future. This reversibility, inspired by Newtonian physics freezes time as a dimension, the positivist analysis becomes atemporal and ahistoric (Prigogine and Stengers, 1984: 68; Wallerstein, 1995: 252-254, Isen, 1995a: 5).

In both natural and social sciences, time is an absolute, controllable and measurable component of positivist analysis in the Galilean and Cartesian sense (Gleick -?-; 56-57). Yct, since Einstein first posed the theory of relativity, time has stopped being conceived of an absolute category in physics, but as relative to space and motion. Heisenberg's "Uncertainty Principle" and Quantum Mechanics of subatomic particles have shown that at least under certain conditions, even mater ceases to be a "real reality". More recently, Bénard's Instability has established in hydrodynamics that moleculcs far from a state of equilibrium "seck and find" equilibrium again in unpredictible ways. Chaos Theory in mathematics studying complex systems has concluded that despite an underlying order, certain phenomena simply defy prediction. Such discoveries have undermined a very basic tenet of positivist science by showing the futility of trying to reach universal determinisms even in "positive" sciences. The common aspect of all these contemporary theories is that they consider time not as a controllable constant but as a temporal variable of the phenomena under investigation (Prigogine, 1993: 19-22; Isen, 1995: 5). The inclusion of temporality as a dimension of scientific inquiry has laid open to questioning the positivist reliance on and reliability of objectivity and deterministic predictions (Prigogine, 1993: 22). The new emphasis on the "timc arrow"; temporality as a necessity of the natural sciences has placed the positivist paradigms of physics in an untenable position (See Prigogine; 1993). Yet as late as mid 1980 's, positivism's appeal has continued in the social sciences (Sce Nicholson; 1993). In IR, an examplar neorealist Robert Keohane (1986: 1-3), while defending the usefulness of theory in the discipline, complained that theories of world politics are riddled with the scholars' value systems, personal experiences and temperaments, whereas scientific theorics such as Newtonian physics provide powerful, value free explanations.

The atemporal approach of positivist social theory, accepting the here and now empirical reality of phenomena as a universal and reversible given, implicitly lades them with an unchangeability bearing inevitable ideological implications. Thus, society, including its values and norms is assumed as a 
constant given with all its structures and processes; a phenomenon that has achicved a level of maturity and perfection that has no need any longer for fundamental changes within the time arrow (Isen, 1995a: 5). A good example of this attitude is the positivist theory of modernisation, devised to explain the difference among members of the international community on a certain "scale of development". Modernist discourse in effect, is a meta-language ideology which tells people how they should live imposing the model of the Western "modern" society as a "telos", an objective to be achieved if any society intends to be anything of value. The term modern, furthermore, serves a linguo-ideological function as an expression of not "bcing modern" but the "consciousness of being modern"; by thus separating what is modern from what is not (Alexander, 1995: 69-70).

\section{The Critics of the Positivist "Ideology":}

The positivist claim to objectivity is founded on a technical rationality that draws on quantitative and statistical techniques extensively in order to measure not what ought to be, but what is. This technical rationality is in turn the basis of positivism's claim to "the end of ideology in (social) science" by analyzing phenomena empirically hence objectively; leaving out values, norms or personal preferences of the scientist. It is this apparent objective and non-ideological virtue of empirical positivism that underlies its academic appeal (Ashley, 1984: 250; Linklater, 1990: 9).

This appeal has naturally found a voice in IR as well. All information in the ficld since the Second World War has been centred on one variant of a "spectator theory of knowledge" or another; as Jim George (1993: 204) has put: "The knowledge of the real world is glcaned via a realm of external facts which impose themselves on the scholar/statesman who is then constrained by the policy/analytical art of the possible".

The epistemological roots of realism in IR as a positivist science stretch as far back as post-Enlightenment, post-Cartesican rationalism of Western European philosophy and the socio-political discourse of the epoch. The rationalist assumption of a correspondence between theory and empirical fact is of dubious standing since Hume; however this dichotomy has underlied positivist theory in all aspects, including realist IR theory (George, 1993: 202). In the latter half of the 20th century, it has emerged as the sole theory of IR simultaneously with the rise of the U.S.A. to the center of the complex web of world relations as a leader and the most active member of the international community. The political world role of the U.S. was formulated in its rather ideological designation as "the leader of the free world" and the need for a scientific analysis of this new position was answered through the adoption of realism in scholarly circles. In this aspect, realism is and has always been an American science born and developed in response to American priorities. During the Cold War, the pover politics have rendered realism the 
paradigm in IR; reflecting in Rothstein's (1972: 350) phraseology as "the catechism of intellectual and policy making circles". Realism as a doctrine centered on traditional balance of power dictates formulations of collective security, with a state centric, anarchical theory of power politics, dealing primarily with maintaining the status quo (Hoffman: 1992: 37-42). The neorealists (Waltz, Gilpin, Krasner, Keohane) who followed first generation scholars such as Morgenthau, Carr, Kissinger or Wight maintained the state centric, power oriented, anarchically structured aspects of political theory of a world which ran on balance of power and in the name of scientism, dressed up the theory with the "then-in" systems approach, empirical reductionism and other acceptable paraphernalia of positivistic empirical technicality that enabled the study of the "world out there" (Gcorge; 1993: 212).

On an overall view, the realist tradition studied the "world out there" as an image frozen in time, leaving the meta processes such as history, which figured largely in the emergence of this image out of the equation and neglecting that aspect of reality which can be subject to change as a result of the interaction between theory and practice. In other words, an approach questioning how and why theoretical frameworks ever come into being was never incorporated into the positivist-realist tradition of science. On the other side of the fence, the anti-positivist Critical Theory of IR, evolving from the ideas of the Frankfurt School has and does strive to establish and emphasize the connection between social phenomena, the lives of individuals, historical processes and theories. Thus, the everyday practice of power is reconnected with theoretical knowledge and the debate foreclosed by realism on how we come to know and create reality. Critical Theory does not posit an atemporal, ahistorical, continuing present but is oriented toward a continuing process of historical change (George, 1993: 218).

\section{Within the "Thinking Space"; International Theory as}

In the 1990's, the new, post-positivist approaches in international theory, whether they come under the name critical, reflexive, poststructuralist or post modern, have created a "thinking space" [to use the lexicon of Jim George (1989)] and have relieved it from the monopolistic hold of the realist paradigm representing only a fragment of social theory as a whole. Now, IR theory faces the tempo-expansive (spread in time) vistas of alternative paradigms; different perspectives of reality which link social relationships and processes with every dimension of human life and experience. As a scientific discipline, IR now progressively integrates both with the history, present and future of social structure and with evolving intellectual systems through an inquiry into not only its assumptions of science, but the mental constructs lying at the bases of those assumptions as well; hence, it advances on the path of conceptual variegation other social or even natural sciences have long achicved. In the light of pluralism in 
theoretical approaches, truth is spread before the scientist, not merely via empirical observation and experiment, but also with its temporal dimensions involving transformation and uncertainty; whose analysis rejects restriction to a monopoly of aesthetic perceptions, control and prediction only. With the advent of plural epistemologies in international theory, the formations among states so far studied from a single viewpoint and the form of knowledge considered the privilege of a limited sphere of scholars adhering to that vista, opened up to analysis as an element of social, even personal experience. The positivist criteria of scientific knowledge are no longer acceded to be adequate in understanding the machinations of our world, both in the natural and social spheres. Contemporary findings of physics have shed a light on theoretical and epistemological debates; and an cxpanding agreement is observed in the social sciences on a requirement for creating new conceptual frames of reference.

During the years of heated debates on methodological issues in social science, IR theory, safe in the haven realism provided, spent its time attending limited issues with limited instruments; unperturbed by the tumults of epistemological difference and conflict. Now, if it is to deserve a scientific status, IR theory has to become both the field of inquiry and the subject of analysis of all the paradigms applied to the study of social life, of which it is an integral part. Perhaps the 1990's signify a turning point in the history of IR: By claiming its snare of the epistemological heritage and wealth of other sciences, the sheer "discipline" faces the chance to mature into a "Sociology of International Relations". For half a century, the discipline has enjoyed a methodological and philosophical homogeneity and lack of dissent unequaled in any scientific endeavor since scholasticism. At this justion, international theory, just as all the rest of the spectrum of social sciences, is in the process of getting more decply involved in a clash of paradigms which all sciences must accept as a norm of maturity. Considering that a growing share of the discipline's literature in the last two decades aims to bridge the hiatus between the philosophy and sociology of science and IR, it is not very long before international theory attains that maturity - in fact, if it already has not.

\section{BIBLIOGRAPHY}

Jeffrey C. Alexander, "Modern, Anti, Post and Neo", New Left Review, 210 (1995).

Gabricl Almond and G. Bingham Powell, Comparative Politics: System, Process and Policy, Boston, Little Brown Pub., , 1978.

Richard K. Ashley, "The Poverty of Neorealism", International Organization, 38, (spring 1984). 
Büşra Ersanlı Behar, İktidar ve Tarih: Türkiye'de Resmi Tarih Tezinin Oluşumu (1929-1937), İstanbul, Afa Yayınları, 1992.

Montgomery Norman Birnbaum, The Radical Renewal: The Politics of Ideas in Modern America, New York, Panthcon, 1988.

Burcu Bostanoğlu, "ABD'nin Latin Amerika Retoriğinden Örnekler", Avrasya Dosyası, 1995, 114-131.

T.B. Bottomore, Toplumbilim, Çev. Ünsal Oskay, Ankara, Doğan Yayınları, 1977.

Hedley Bull, "The Theory of International Politics, 1919-1969" in Brian Porter (ed.) Abertswyth Papers: International Politics, 1919-1969. Oxford University Press, 1972.

Robert Cox, "Social Forces, States and World Orders: Beyond International Relations Theory", in Richard and Little, Michacl Smith, eds., Perspectives on World Politics, London, Routledge, 1992.

R.W. Cox, "Social Forces, States and World Orders" in Robert Keohene, ed., Neorealism and Its Critics, New York, Columbia University Press, 1986.

James Der Derian, Michael Shapiro, International Intertextual Relations: Postmodern Readings of World Politics, Lexington, Lexington Books, 1989.

Jim George, "International Relations and the Search for Thinking Space: Another View of the Third Debate", International Studies Quarterly, 33. (1989).

Jim George, David Campbell, "Patterns of Dissent and the Celcbration of Difference: Critical Social Theory and International Relations", International Studies Quarterly, 34, 1990, pp. 269-293.

Stephen Gill, American Hegemony and the Trilateral Commission, Cambridge, Cambridge University Press, 1990.

S. Gill, D. Law, The Global Political Economy, Perspectives, Problems and Policies, Whcatsheaf, Hertfordshire, Harvester, 1988. 
James Gleick, Kaos, İstanbul, Evrin Yayınevi, Bilim Dizisi 1, (Tarihsiz).

Mark Hoffman, "Restructuring, Reconstruction, Reinscription, Rearticulation: Four Voices in Critical International Theory", Millennium, The Journal of International Studies, 20, (Summer 1991).

G. B. Isen, Saldırganlık Kuramları ve Basında Cinayet Haberleri, Basılmamış Doktora Tezi, Gazi Üniv. S.B.E., Ankara, 1995.

I. Isen, "Brecht'in Eşeği, Gerçek, Bilim ve Şair Vehbi", Bodrum Postası, No 43, 16 Kasım 1995, s. 5.

Robert O. Keohane, Realism, Neorealism and the Study of World Politics, Keohane, Ed. 1986.

Thomas S. Kuhn, The Structure of Scientific Revolutions, University of Chicago Press, 1962.

Imre Lakatos and A. Musgrave, Eds., Criticism and the Growth of Knowledge, Cambridge, Cambridge University Press, 1970.

Andrew Linklater, Beyond Realism and Marxism: Critical Theory and International Relations, London, MacMillan, 1990.

Richard Little, "The Evolution of International Relations as a Social Science", International Relations, London, Francis Pinter, 1980, pp. 1-27.

Mark Neufeld, "Reflexivity and International Relations Theory", Millenium: Journal of International Studies, V. 22, (1993).

Christopher Norris, "Truth, Science, and the Growth of Knowledge", New Left Review, No. 210, 1995.

Nicholas Onuf, World of Our Making: Rules and Rule in Social Theory and International Relations, Comumba, University of South California Press, 1989.

Ilya Prigogine, "Science and Our Understanding of the World", Transition to a Global Society, Oxford, Oncworld Publications Lid., 1993.

I. Prigogine, Isabelle Stengers, Order Out of Chaos, New York, Bantam Books, 1984. 
R. Rothstein, "On the Costs of Realism", Political Science Quarterly, $87,(1972)$.

A. Sclami Sargut, Kültürlerarası Farklılaşma ve Yönetim, Ankara, Verso Yayınları, Nisan 1994.

Ali Yaşar Sarıbay, Siyasal Sosyoloji, İstanbul, Der Yayınları, 1994.

D. Michacl Shafer, Deadly Paradigms: The Failure of US Counterinsurgency Policy, Princeton, Princeton University Press, 1988.

Steve Smith, "Paradigm Dominance in International Relations: The Development of International Relations as a Social Science"; Millenium, Journal of International Studies, 16, (1987).

Barlas Tolan; Sosyoloji, Ankara, Adım Yayıncılık, 1993.

R. B. J. Walker, Inside/Outside: International Relations as Political Theory, Cambridge Mass., Cambridge Univ. Press, 1993.

Immanuel Wallerstein, "Sosyal Bilimler Nereye Gidiyor?", M. Özel, Ed., Tarih Risaleleri, İstanbul, İ\% Yayıncılık, 1995.

Kenneth N. Waltz, Theory of International Politics, Reading, Mass., Addison-Wesley, 1979. 